\title{
WATER STRESS TOLERANCE OF FODDER COWPEA AS INFLUENCED BY VARIOUS ADDED LEVELS OF POTASSIUM SULPHATE
}

Zeinab M. Khalil ${ }^{1}$; Azza Kh. Salem ${ }^{2}$ and Fadia M. Sultan ${ }^{2}$

${ }^{1}$ Soils, Water and Environment Research Institute, Agric. Res. Center, Giza, Egypt.

${ }^{2}$ Forage Research D., Crop Research Institute, Agric. Res. Center, Giza, Egypt.

\begin{abstract}
A field experiment was carried out on sandy soil of the Agricultural Research Experimental Station, at Ismailia Governorate (latitude $30^{\circ} 35^{\prime} 41.9^{\prime \prime} \mathrm{N}$ and longitude $32^{\circ} 16^{\prime} 48.8^{\prime \prime}$ E), Egypt, during two successive growing summer seasons; 2013 and 2014. The study aimed to investigate the effect of applying three levels of water supplied through sprinkler irrigation system representing; $100 \%, 75 \%$ and $50 \%$ of water supply which corresponding to 2500,1875 and $1250 \mathrm{~m}^{3} \mathrm{fed}^{-1}$, on the forage yield productivity and quality of fodder cowpea. Such levels represented commonly practiced irrigation (control), moderate and severe water deficit stress for fodder cowpea, respectively. Also, to evaluate the role of four rates of potassium sulphate fertilization namely, 24, 36, 48 and $60 \mathrm{~K}_{2} \mathrm{O} \mathrm{kg} \mathrm{fed}{ }^{-1}$ in alleviating the adverse effect of water deficit stress on cowpea plants under these conditions. Three cuts were taken throughout the growth season. The obtained results revealed that decreasing the levels of water from $100 \%$ to 75 or $50 \%$ level markedly reduced all traits under studied; plant height, leaves number per plant, leaves/stem ratio of cowpea, green and dry forage yield $\left(\mathrm{kg} \mathrm{fed}^{-1}\right)$, at the three cuts as well as the total yield of the three cuts. The reduction noticeably appeared more detrimental under $50 \%$ of water stress especially at the $3^{\text {rd }}$ cut. The results showed that the total green and dry forage yield of the three cuts of plants treated with $48 \mathrm{~kg} \mathrm{~K}_{2} \mathrm{O} \mathrm{fed}{ }^{-1}$, under $50 \%$ irrigation level, reduced by $52.4 \%$ and $57.0 \%$, respectively; compared with the yields obtained by plants received the recommended $\mathrm{K}$ rate $\left(48 \mathrm{~kg} \mathrm{~K}_{2} \mathrm{O}\right.$ fed $\left.{ }^{-1}\right)$ under commonly practiced irrigation. Increasing water deficit stress lowered carbohydrate \%, crude proteins \% and ash content $\left(\mathrm{kg} \mathrm{fed}^{-1}\right)$ in plants as well as $\mathrm{K} \%$ in leaves. Also, it significantly decreased the contents of $\mathrm{Fe}, \mathrm{Zn}$ and $\mathrm{Mn}$ in plants.

Increasing the application rates of $\mathrm{K}$ up to $60 \mathrm{~K}_{2} \mathrm{O} \mathrm{kg} \mathrm{fed}{ }^{-1}$ substantially elevated all the aforementioned studied traits under each level of irrigation and the reduction resulted due to water stress, under $75 \%$ and $50 \%$ levels could be suppressed. Application of the highest $\mathrm{K}$ rate $\left(60 \mathrm{~K}_{2} \mathrm{O} \mathrm{kg} \mathrm{fed}{ }^{-1}\right)$ not only considerably heightened all the detected nutrients; carbohydrate $\%$ and proteins $\%$, ash and micronutrients ( $\mathrm{Fe}, \mathrm{Zn}$ and $\mathrm{Mn}$ ) uptake by plants as well as $\mathrm{K} \%$ in leaves of cowpea, but also it remarkably enhanced the water use efficiency by plants grown under $75 \%$ irrigation than all applied $\mathrm{K}$ rates treatments under $100 \%$ irrigation.

From the obtained results, it could be inferred that under moderate water stress $75 \%$ of the commonly practiced irrigation application of $60 \mathrm{~K}^{2} \mathrm{O} \mathrm{kg} \mathrm{fed}{ }^{-1}$ could sustain cowpea plant to grow satisfactorily.
\end{abstract}

Keywords: Water stress- Fodder cowpea- Drought stress tolerance- Potassium sulphate.

\section{INTRODUCTION}

Cowpea, (Vigna unuuiculata L.) Walp, is an important source of protein, phosphorus, minerals and certain soluble vitamins in human diet (Karigoudar and Angadi, 2005), and is equally important as nutritious fodder 
for livestock (Singh et al., 2003). The grains are used as human food whereas its stems and leaves are good fodder for livestock. As a legume fodder, it provides high quality forage rich in proteins (14-24\% DM) (Heuzé et al., 2013); that allows it to be used as a notorious supplement to livestock diets based on cereal forage or with other low- quality forages to increase their nutritive values (IITA, 1989).

Late- maturing varieties (> 120 days) are generally used for fodder because they can take advantage of a longer growing season to amass more biomass (IITA, 1989). Fodder cowpea is characterized by quick growing, produces substantially rich biomass. It grows successfully on a wide variety of soils provided they are well drained (Madamba et al., 2006), nevertheless, it performs better in light sandy loam or sandy soil that are less restrictive to root growth. It has the ability to tolerate drought; can withstand heat and can utilize soil moisture efficiently as it has a well-developed root system (Sambo et al., 2013). As an $\mathrm{N}$-fixing legume, fodder cowpea is particularly useful for building up soil fertility by increasing soil $\mathrm{N}$ and restoring soil fertility for the subsequent crops when including in crop rotation with cereal crops (Mullen, 1999). Additionally, it can be used as a cover crop during summer without demanding too much water (Ledbetter, 2005). Moreover, cowpea forage is used as a green manure by providing soils with readily available, biologically fixed N (Creamer and Baldwin, 1999).

In Egypt, fodder cowpea is used to compensate the green fodder shortage in animal feed in summer and autumn and also to enhance profitable production for the farmers.

In Egypt, augmenting the green forage production is of prime importance. Nevertheless, the newly reclaimed soils, thereat, are generally poor sandy soils deficient in nutrients, with limited water supply and characterized by drought conditions. Water deficit and Drought are the most limiting factors affecting plant growth; reduce crop production and threatening food security in the world (Baker, 1989).

Egypt, like many other countries which lie in arid and semi-arid region, is subjected to water scarcity $(F A O, 2013)$. Climate change (rising of temperature and lowering of precipitation), misuse of water resources, pollution and inefficient agriculture irrigation techniques besides rapid rising of population are the major factors that aggravate water security problem in the country (Dakkak, 2013).

Mineral nutrients play a critical role in plant stress resistance (Marschner, 1995). Out of all the mineral nutrients, Potassium (K) is privileged to improve water relations and particularly contributes greatly to the survival of plants when grow under various biotic and abiotic stress (Wang et al., 2013). It is the principal solute contributes to osmotic adjustment and lower water potential of plant cells; a mechanism contributes to turgor maintenance of plant cells when experience water deficit stress (Sánchez et al., 2004 and Zlatev and Lindon, 2012).

Numerous investigations demonstrated that adequate supply of $\mathrm{K}$ increased tolerance of crops to drought stress and improved water use efficiency in plants as well as augmented the performance and yield of many 
crops; sunflower (Soleimanzadeh et al., 2010), peanut (Aboelill et al., 2012), fodder beet (Kassab et al., 2012) and wheat (Ghaznavi and Abdolshahi, 2011; Samar Raza et al., 2013 and Zareian et al., 2013).

Aboelill et al., (2012) found that water stress significantly reduced the yield of peanut by the decreasing of water regimes from $100 \%$ to $80 \%$ or $60 \%$ water supply, however, spraying peanut plants with $1 \%$ liquid $\mathrm{K}_{2} \mathrm{SO}_{4}\left(800 \mathrm{~cm}^{3}\right.$ $\left.\mathrm{fed}^{-1}\right)$ markedly increased number of branches, dry matter of stem and whole plants as well as dry matter of pods.

The present investigation aimed at studying the effect of water deficit stress on forage yield productivity and quality of fodder cowpea, grown under sandy soil conditions and evaluating the role of different potassium application rates on enhancing the tolerance of cowpea plants to water deficit stress.

\section{MATERIALS AND METHODS}

A field experiment was conducted at the Agriculture Research Station farm of ARC, in Ismailia Governorate (latitude $30^{\circ} 35^{\prime} 41.9^{\prime \prime} \mathrm{N}$ and longitude $32^{\circ} 16^{\prime} 48.8^{\prime \prime}$ E), Egypt, during the two successive summer seasons; 2013 and 2014. The study aimed at investigating the effect of four levels of potassium fertilization in the form of $\mathrm{K}_{2} \mathrm{SO}_{4}$ namely; 24, 36, 48 and $60 \mathrm{~K}_{2} \mathrm{O}$ fed $^{-1}$ on productivity and quality of fodder cowpea cultivated in sand soils under three levels of irrigation; $100 \%, 75 \%$ and $50 \%$ of water supply. These levels represented conventional crop water requirement in the region besides those could cause, moderate and severe water deficit stress; $75 \%$ and $50 \%$ of water requirement, respectively.

Before planting, physical and chemical characteristics of the soil were determined by methods outlined by piper (1950), Black (1982) and Page et al., (1982). Such analyses revealed that soil texture of the experimental site was sandy, having $\mathrm{pH} 7.8$ (1:2.5 soil: water suspension), $0.50 \% \mathrm{OM}$ content, EC was $1.59 \mathrm{dSm}^{-1}$ and available $\mathrm{N}, \mathrm{P}$, and $\mathrm{K}$ contents were 34, 2.9 and 150 $\mathrm{mgkg}^{-1}$, respectively.

The experiment was laid out in a split plot with complete randomized block design with three replications. The main plots were devoted to the three water irrigation levels while the subplots were assigned for the four potassium rates. The area of the subplot was $12 \mathrm{~m}^{2}$ (4 m length $\times 3 \mathrm{~m}$ width). Before planting, during soil preparation, all plots were fertilized with a basal dose of super phosphate $\left(15.5 \% \mathrm{P}_{2} \mathrm{O}_{5}\right)$ at a rate $200 \mathrm{~kg} \mathrm{fed}^{-1}$. Nitrogen fertilizer was applied as urea $(46 \% \mathrm{~N})$ at a rate of $40 \mathrm{~kg} \mathrm{fed}^{-1}$ split in three doses; half after thinning and one quarter after the $1^{\text {st }}$ cut and the other one after $2^{\text {nd }}$ cut. Each level of potassium sulphate $\left(48 \% \mathrm{~K}_{2} \mathrm{O}\right)$ fertilizer was split in two equal doses, being added after thinning and after the $1^{\text {st }}$ cut. Seeds of cowpea were sown on $25^{\text {th }}$ May in 2013 and on $20^{\text {th }}$ May in 2014; at a rate of $25 \mathrm{~kg}$ seeds fed $\mathrm{fin}^{-1}$ rows $20 \mathrm{~cm}$ apart. Before sowing the seeds were inoculated with a commercial bio- fertilizer having Rhizobia, specific bacteria for cowpea, 
obtained from the Agriculture Research Center. Inoculation was performed by mixing the seeds thoroughly with the bio-fertilizer at a rate of $250 \mathrm{~g} / 25 \mathrm{~kg}$ seeds, using Arabic gum as an adhesive material. After complete emergence of seedlings plants were thinned to one plant a hole.

Irrigation was performed through sprinkler irrigation system every day in summer and every 2-3 days in autumn. The amount of water applied for each irrigation treatment was calculated according to the crop coefficient $(\mathrm{Kc})$ and the daily reference evapotranspiration (ETo); determined according to the Penman-Monteeith equation depending on the predicted climatic factors, according to Allen et al.., (1992). At the end of each growing season, the quantity of water applied for the three irrigation treatments was calculated in $\mathrm{m}^{3}$ fed ${ }^{-1}$. The average amounts of applied water from sowing until harvesting were 2500,1875 and $1250 \mathrm{~m}^{3} \mathrm{fed}^{-1}$ for the three irrigation treatments, respectively.

Three cuts were taken through the growing season; the $1^{\text {st }}$ one was taken after 45 days from sowing, the other two cuts were taken subsequently every 40 days. Clipping was performed $20 \mathrm{~cm}$ from soil surface to allow the growth for the subsequent cutting.

\section{The studied characters included:}

\section{Growth parameters:}

before cutting, number of leaves per plant was counted, height $(\mathrm{cm})$ of five plants for each treatment were measured and recorded as well as estimating leaves/ stem ratios, on fresh weight basis.

\section{Forage yield:}

fresh forage yield was appraised by clipping three middle row- plants from each subplot and weighed then converted to yield $\mathrm{Mg} \mathrm{fed}^{-1}$. Fresh forage from each treatment was dried at $70 \stackrel{\circ}{\circ}$ to constant weight and dry forage yield $\left(\mathrm{Mgfed}^{-1}\right)$ was determined.

Chemical analyses:

$0.5 \mathrm{~g}$ of ground dry matter, representing leaves and/or whole plants, was taken from each treatment and digested with $\mathrm{H}_{2} \mathrm{SO}_{4}$ and $\mathrm{HClO}_{4}$ acid. Nutrient contents were determined in the digested solution of the dry matter. Nitrogen was determined in the digested solutions of whole plant by micokjeldahl according to AOAC (1990) and N \% values were multiplied by 6.25 to obtain the crude protein \%. Crude ash concentration (\%) was determined according to AOAC (1990). Total carbohydrates \% was determined in the dry matter of whole plants, using the method described by Dubois et al., (1956). Potassium was detected in the digested solution of leaves, by a flame photometer according to Chapman and Pratt (1982). Fe, Mn and $\mathrm{Zn}$ were detected by the atomic absorption (model GBC 932).

Water use efficiency (WUE):

The amount of biomass produced per unit of water consumed; WUE values $\left(\mathrm{kg} \mathrm{m}^{-3}\right)$ of green and dry forage yield of fodder cowpea, at each cut and total three- cut yield, for each treatment was calculated according to the following equation (Jensen, 1983).

WUE $\left(\mathrm{kg} \mathrm{m}^{-3}\right)=$ Green or dry forage yield $\left(\mathrm{kg} \mathrm{fed}^{-1}\right)$

Seasonal applied water $\left(\mathrm{m}^{3} \mathrm{fed}^{-1}\right)$ 


\section{Statistical Analysis:}

All data were subjected to statistical analysis according to Steel and Torrie (1984). Least significant differences (L. S. D.) at 0.05 probabilities were estimated for comparing means.

\section{RESULTS AND DISCUSSION}

\section{Growth characters}

The effects of irrigation levels and different rates of $K$ on growth characters; plant height, leaves number per plant and leaves /stem ratio, on fresh weight basis, are shown in Table (1).

Data indicated that irrigation water levels had a significant effect on all those parameters. Decreasing the irrigation water levels than the commonly applied level (100\%) markedly reduced all the studied growth characters, at the three cuts. The inhibiting effect of the water deficit stress, on the studied characters, notably appeared more detrimental under 50\% irrigation level than $75 \%$ level. This is may refer to that decreasing the irrigation water lowered the soil moisture content which restricted the mobility of nutrients to plant that would reduce the efficiency of physiological and metabolic processes needed for plant growth. Fatthallah and Gawish (1997) and Kassab et al., (2012) reported similar results. Shortening of the plant height due to lowering irrigation levels could be attributed to the decrease in plant water content and turgor pressure that negatively affecting cell division and enlargement (cells turgidity), consequently, causing reduction in the activity of the meristematic tissues responsible for elongation, growth and development of a plant. Similar findings were obtained by Aboelill et al., (2012), Okon (2013) and El Sarag (2013).

Under common irrigation treatment (100\%), elevating application rate of $\mathrm{K}$ significantly increased plant height and leaves numbers. The highest enhancement, in both, was attained with the highest applied $\mathrm{K}$ rate; $60 \mathrm{~kg}$ $\mathrm{K}_{2} \mathrm{O}$ fed $^{-1}$. Under 75 and $50 \%$ levels, elevating the applied $\mathrm{K}$ rates also, markedly heightened these growth parameters yet the adverse effect due to water deficit stress on such traits might be alleviated.

Regarding the leaves /stem ratio, the results revealed that, the values of this ratio were greatly affected by the irrigation water levels and application $\mathrm{K}$ rates, as these values were very high under normal irrigation, especially with the highest applied $\mathrm{K}$ rates. This is could be related to the increasing number and weight of leaves as well as length and weight of shoots; accompanied all K-treatments. Nevertheless, a reverse trend was found under the lowest irrigation one. The lowest values of this ratio under $50 \%$ irrigation level might be as a result of decreasing area and numbers of leaves, promotion of their senescence and abscission under drought condition as reported by Karamanos (1980) and Hayatu and Mukhtar (2010).

Statistical data in (Table 1) show no significant differences between leaves /stem ratio values of cowpea plants treated with the highest $\mathrm{K}$ rate; 60 
$\mathrm{kg} \mathrm{K}_{2} \mathrm{O}$ fed $^{-1}$ under $75 \%$ irrigation level and the corresponding values that accompanied with the recommended application $\mathrm{K}$ rate $48 \mathrm{~kg} \mathrm{~K}_{2} \mathrm{O}$ fed ${ }^{-1}$ under $100 \%$ irrigation level, at the three cuts.

Table (1): Effect of water irrigation levels and different application rates of $\mathrm{K}$ on plant height, leaves No. and leaves/stem ratio of fodder cowpea (over two seasons).

\begin{tabular}{|c|c|c|c|c|c|c|c|c|c|c|}
\hline \multirow{2}{*}{$\begin{array}{l}\text { Treatment } \\
\text { Irrigation } \\
\text { levels(A) }\end{array}$} & \multirow{2}{*}{$\begin{array}{c}\text { Rates } \\
\text { of } \mathrm{K}_{2} \mathrm{O} \\
\text { (B) }\end{array}$} & \multicolumn{3}{|c|}{$\begin{array}{l}\text { Plant height } \\
\text { (cm) }\end{array}$} & \multicolumn{3}{|c|}{ 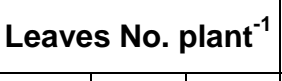 } & \multicolumn{3}{|c|}{ Leaves/stem ratio } \\
\hline & & Cut 1 & Cut 2 & Cut 3 & Cut 1 & Cut 2 & Cut 3 & Cut 1 & Cut 2 & $\mathrm{Cu}$ \\
\hline \multirow{4}{*}{$100 \%$} & 27 & 85.0 & 86.0 & 71.3 & 20 & 21 & 15 & 1.570 & 103 & 0.80 \\
\hline & 36 & 88.0 & 90.0 & 78.0 & 25 & 28 & 16 & 1.673 & 1.440 & 1.01 \\
\hline & 48 & 94.0 & 96.0 & 85.0 & 28 & 30 & 19 & 1.690 & 57 & 1.16 \\
\hline & 60 & 102.7 & 98.7 & 90.1 & 32 & 33 & 22 & 1.780 & 03 & .25 \\
\hline \multicolumn{2}{|c|}{$A_{1}$ Mean } & 92.4 & 92.7 & 81.2 & 26.3 & 28.0 & 18.0 & 1.678 & 1.376 & 1.06 \\
\hline \multirow{4}{*}{$75 \%$} & 24 & 60.0 & 63.0 & 46.2 & 14 & 13 & 12 & 1.430 & 1.113 & 0.64 \\
\hline & 36 & 69.0 & 71.0 & 54.0 & 18 & 17 & 13 & 1.587 & 1.263 & 0.99 \\
\hline & 48 & 80.0 & 82.0 & 65.0 & 19 & 20 & 15 & 1.670 & & 1.11 \\
\hline & 60 & 86.0 & 88.7 & 74.7 & 21 & 24 & 18 & & 73 & 14 \\
\hline \multicolumn{2}{|c|}{$\mathrm{A}_{2}$ Mean } & \begin{tabular}{|l|}
73.8 \\
\end{tabular} & \begin{tabular}{|l|}
76.2 \\
\end{tabular} & 59.9 & 18.0 & 18.5 & 14.5 & 1.600 & 1.316 & 0.97 \\
\hline \multirow{4}{*}{$50 \%$} & 24 & 45.0 & \begin{tabular}{|l|}
43.0 \\
\end{tabular} & 27.0 & 10 & 11 & 8 & 0.620 & 0.537 & 0.38 \\
\hline & 36 & 56.0 & 50.0 & 32.0 & 11 & 12 & 9 & 0.633 & 0.540 & 0.40 \\
\hline & 48 & 60.7 & 58.0 & 40.1 & 13 & 13 & 11 & 0.783 & 0.720 & 0.58 \\
\hline & 60 & 65.0 & 96.0 & 45.0 & 15 & 16 & 13 & 0.987 & 0.823 & 0.61 \\
\hline \multicolumn{2}{|c|}{$\mathrm{A}_{3}$ Mean } & \begin{tabular}{|l|}
56.7 \\
\end{tabular} & 55.0 & 36.0 & 12.3 & 13.1 & 10.6 & 0.745 & 0.655 & 0.49 \\
\hline \multirow{4}{*}{$\begin{array}{l}\text { Means of K- } \\
\text { rates } \\
\text { (B) }\end{array}$} & 24 & 63.3 & 64.0 & 48.1 & 14.7 & 15.1 & 11.9 & 1.207 & 0.918 & 0.61 \\
\hline & 36 & 71.0 & 70.3 & 54.7 & 18.0 & 19.0 & 12.9 & 1.298 & 1.081 & 0.80 \\
\hline & 48 & 78.0 & 78.7 & 63.3 & 20.0 & 21.0 & 15.0 & 1.381 & 1.197 & 0.95 \\
\hline & 60 & 84.7 & 85.4 & 69.9 & 22.6 & 24.3 & 17.7 & 1.493 & 1.267 & 1.00 \\
\hline \multicolumn{11}{|c|}{ L.S.D at $5 \%$} \\
\hline \multicolumn{2}{|l|}{$\frac{A}{B}$} & 1.9 & 1.7 & 2.1 & 1.7 & 0.8 & 2.1 & 0.116 & 0.029 & 0.07 \\
\hline \multirow{2}{*}{\multicolumn{2}{|c|}{$\frac{B}{A \times B}$}} & 2.5 & 1.8 & 1.9 & 1.6 & 1.5 & 1.4 & 0.061 & 0.038 & 0.05 \\
\hline & & 3.9 & 3.1 & 3.3 & 2.8 & 2.6 & ns & 0.106 & 0.065 & 0.09 \\
\hline
\end{tabular}

This could be interpreted as application of an adequate supply of $\mathrm{K}$ $\left(60 \mathrm{~kg} \mathrm{~K}_{2} \mathrm{O} \mathrm{fed}{ }^{-1}\right)$ under moderate water deficit stress may improve the water status of K-treated plants that reflected on performance of various physiological processes efficiently. Alleviating the detrimental effect of drought stress by sufficient $\mathrm{K}$ supply was shown in legume by Sangakkara et al., (2000) and Aboelill et al., (2012).

\section{Green and dry forage yield}

Data presented in Table (2) show the effects of irrigation levels and different application $\mathrm{k}$ rates on green and dry forage yield $\left(\mathrm{Mg} \mathrm{fed}^{-1}\right)$ of fodder cowpea, at the three cuts, and their total yield over the three cuts $\left(\mathrm{Mg} \mathrm{fed}^{-1}\right)$.

The results revealed that both green and dry forage yield of cowpea markedly reduced with the decrease of irrigation water level i.e., by increasing water deficit stress, at the three cuts. Both yields were severely reduced when plants irrigated by $50 \%$ level, especially, at the $3^{\text {rd }}$ cut. Similar 
trend was noticed with the total fresh and dry three-cut yields. Water stress, under $50 \%$ irrigation, reduced total fresh and dry forage yield produced by cowpea plants received $48 \mathrm{~kg} \mathrm{~K}_{2} \mathrm{O}$ fed $^{-1}$ by $52.4 \%$ and $57.0 \%$, respectively; compared with the yield obtained when $48 \mathrm{~kg} \mathrm{~K}_{2} \mathrm{O}$ fed ${ }^{-1}$ was applied under $100 \%$ irrigation (Table, 2). In this regard, Wang et al., (2003) found that drought stress reduced average yield for most major crops by more than 50 $\%$.Also, Our results in accordance with those obtained by Hayatu and Mukhtar (2010) who found that moderate water stress significantly reduced above ground biomass of seven genotypes of cowpea and the reduction was greater under severe water stress. In the current study, the results revealed that application of $\mathrm{K}$ especially with the highest rate; $60 \mathrm{~kg} \mathrm{~K}_{2} \mathrm{O}$ fed considerably enhanced both fresh and dry yields and could diminish the reduction happened in both yield due to water stress, under 75 and $50 \%$ irrigation levels. Application of the highest $\mathrm{K}$ rate; $60 \mathrm{~kg} \mathrm{~K}_{2} \mathrm{O}$ fed ${ }^{-1}$ under common irrigation treatment $(100 \%)$ produced the maximum green and dry forage yields, at the three cuts. Such treatment markedly surpassed the treatment of $48 \mathrm{~kg} \mathrm{~K}_{2} \mathrm{O} \mathrm{fed}^{-1}$; the recommended applied $\mathrm{K}$ rate for fodder cowpea, at normal irrigation condition. The stimulated effect of $\mathrm{K}$-application could mainly be attributed to the enhanced effect of $\mathrm{K}$ on photosynthesis process, enzyme activity and transport of assimilates as mentioned by Marschner (1995).

It is worthy to mention that noticeable increases in the total green and dry yield were achieved as the applied $\mathrm{K}$ rate was augmented. This finding holds true under all tested irrigation levels.

Statistical analysis showed non-significant differences between the values of the green and dry forage yield, as well as their total yield produced by fodder cowpea plants treated by $36 \mathrm{~kg} \mathrm{~K}_{2} \mathrm{O}$ fed ${ }^{-1}$ under $100 \%$ irrigation level and those produced by plants treated by $60 \mathrm{~kg} \mathrm{~K}_{2} \mathrm{O}$ fed $^{-1}$ under $75 \%$ level. From these results it could be concluded that application of the highest $\mathrm{K}$ rate; $60 \mathrm{~kg} \mathrm{~K}_{2} \mathrm{O} \mathrm{fed}{ }^{-1}$ under moderate water deficit ( $75 \%$ level) could have sustained the fodder cowpea to tolerate the water stress. In this regard, Umar (2006) found increased tolerance of sorghum, mustard and groundnut to water stress due to applying sufficient $\mathrm{K}$ nutrition.

The supportive role of $K$ nutrition on yield enhancement of cowpea under water stress conditions could be ascribed to the supposed role of $\mathrm{K}$ on stomatal resistance, water use efficiency and lowering transpiration rate. Similar findings were reported by Umar and Moinuddin (2002) and Umar (2006).

The crucial role of Potassium in turgor regulation within the guard cells of stomata thus regulates the opening and closing of stomata was noticed earlier by Fischer and Hsiao (1968). Anderson et al., (1992) and Kassab et al., (2012) reported that closure of stomata for preservation of internal moisture is an essential mechanism under drought stress, that minimizing water loss via transpiration, hence mitigating the adverse effect of 
drought stress. In this regard, Benlloch-Gonzàlez et al., (2012) indicated that stomata of sunflower plants grown with low levels of $\mathrm{K}$ remained open wider than those of plants with adequate $\mathrm{K}$ supply and this favored transpiration. Moreover, the beneficial effect of applying sufficient $\mathrm{K}$ on enhancing plants drought tolerance through different mechanisms were documented; inhibiting drought-induced toxic oxygen radicals (Cakmak, 2005 and Soleimanzadeh et al., 2010), maintenance of membrane integrity and stability (Bajji et al., 2002) and enhancing photosynthesis, increasing protein synthesis and control ionic balance (Zareian et al., 2013).

Table (2): Effect of irrigation water levels and different application rates of $\mathrm{K}$ on green and dry forage yield $\left(\mathrm{Mg} \mathrm{fed}^{-1}\right)$ of fodder cowpea (mean of two seasons).

\begin{tabular}{|c|c|c|c|c|c|c|c|c|c|}
\hline \multirow{2}{*}{$\begin{array}{l}\text { Treatment } \\
\text { Irrigation } \\
\text { levels }(\mathbf{A})\end{array}$} & \multirow[b]{2}{*}{$\begin{array}{l}\text { Rates of } \\
\mathrm{K}_{2} \mathrm{O} \text { (B) }\end{array}$} & \multicolumn{4}{|c|}{ Green forage yield $\left(\mathrm{Mg} \mathrm{fed}^{-1}\right)$} & \multicolumn{4}{|c|}{ Dry forage yield $\left(\mathrm{Mg} \mathrm{fed}^{-1}\right)$} \\
\hline & & Cut 1 & Cut 2 & Cut 3 & $\begin{array}{l}\text { Total } \\
\text { yield }\end{array}$ & Cut 1 & Cut 2 & Cut 3 & $\begin{array}{l}\text { Total } \\
\text { yield }\end{array}$ \\
\hline \multirow{4}{*}{$100 \%$} & 24 & 3.99 & 3.91 & 2.58 & 10.48 & 0.72 & 0.80 & 0.52 & 2.04 \\
\hline & 36 & 4.25 & 4.36 & 2.74 & 11.45 & 0.76 & 0.88 & 0.58 & 2.22 \\
\hline & 48 & 4.45 & 4.70 & 3.06 & 12.21 & 0.83 & 0.97 & 0.64 & 2.44 \\
\hline & 60 & 4.96 & 5.42 & 3.25 & 13.63 & 0.92 & 1.20 & 0.71 & 2.83 \\
\hline \multicolumn{2}{|c|}{$\mathrm{A}_{1}$ Mean } & 4.41 & 4.59 & 2.91 & 11.94 & 0.81 & 0.96 & 0.61 & 2.38 \\
\hline \multirow{4}{*}{$75 \%$} & 24 & 2.52 & 2.56 & 1.73 & 6.81 & 0.45 & 0.51 & 0.34 & 1.30 \\
\hline & 36 & 2.98 & 2.76 & 1.79 & 7.53 & 0.52 & 0.57 & 0.36 & 1.45 \\
\hline & 48 & 3.84 & 4.13 & 1.97 & 9.94 & 0.64 & 0.85 & 0.41 & 1.90 \\
\hline & 60 & 4.13 & 4.48 & 2.62 & 11.23 & 0.73 & 0.92 & 0.54 & 2.19 \\
\hline \multicolumn{2}{|c|}{$\mathrm{A}_{2}$ Mean } & 3.37 & 3.48 & 2.03 & 8.88 & 0.58 & 0.71 & 0.41 & 1.71 \\
\hline \multirow{4}{*}{$50 \%$} & 24 & 2.03 & 1.31 & 1.02 & 4.36 & 0.35 & 0.26 & 0.18 & 0.79 \\
\hline & 36 & 2.17 & 1.61 & 1.14 & 4.89 & 0.36 & 0.32 & 0.20 & 0.88 \\
\hline & 48 & 2.33 & 2.20 & 1.28 & 5.81 & 0.40 & 0.43 & 0.23 & 1.06 \\
\hline & 60 & 2.63 & 2.84 & 1.37 & 6.84 & 0.45 & 0.58 & 0.27 & 1.31 \\
\hline \multicolumn{2}{|c|}{$\mathrm{A}_{3}$ Mean } & 2.29 & 1.99 & 1.20 & 5.48 & 0.39 & 0.40 & 0.22 & 1.01 \\
\hline \multirow{4}{*}{$\begin{array}{l}\text { Means of K-rates } \\
\text { (B) }\end{array}$} & 24 & 2.85 & 2.59 & 1.78 & 7.22 & 0.50 & 0.52 & 0.35 & 1.38 \\
\hline & 36 & 3.14 & 2.91 & 1.89 & 7.95 & 0.54 & 0.59 & 0.38 & 1.52 \\
\hline & 48 & 3.54 & 3.67 & 2.10 & 9.31 & 0.62 & 0.75 & 0.43 & 1.79 \\
\hline & 60 & 3.91 & 4.25 & 2.41 & 10.57 & 0.70 & 0.90 & 0.50 & 2.11 \\
\hline \multicolumn{10}{|c|}{ L.S.D at $5 \%$} \\
\hline \multicolumn{2}{|l|}{\begin{tabular}{|l|}
$A$ \\
$B$ \\
\end{tabular}} & 0.14 & 0.09 & 0.05 & 0.19 & 0.02 & 0.04 & 0.03 & 0.04 \\
\hline \multirow{2}{*}{\multicolumn{2}{|c|}{\begin{tabular}{|l|}
$\mathrm{B}$ \\
$\mathrm{A} \times \mathrm{B}$ \\
\end{tabular}}} & 0.15 & 0.15 & 0.08 & 0.27 & 0.03 & 0.04 & 0.02 & 0.06 \\
\hline & & 0.26 & 0.25 & 0.14 & 0.46 & 0.05 & 0.06 & 0.03 & 0.10 \\
\hline
\end{tabular}

Statistical data (Tables 1and 2) exhibit that there was a significant interaction effect between irrigation levels and applied K-rates on plant height, leaves number (except at the $3^{\text {rd }}$ cut) and, green and dry forage yields as well as the total yield of fodder cowpea. As decreasing irrigation levels was significantly reduced all of these studied parameters, while increasing application $\mathrm{K}$ rates from 24 to 60 markedly enhanced them under normal irrigation level and could alleviate the negative effect under water deficit levels.

\section{Relative change \% in growth and yield}

Data in Table (3) illustrate the relative change percent exhibited in some studied traits; plant height, leaves number, green and dry forage yield, as affected by the applied treatments; irrigation levels and $\mathrm{K}$ application rates compared to the corresponding values of these traits accompanied with $48 \mathrm{~kg}$ $\mathrm{K}_{2} \mathrm{O}$ fed $^{-1}$ under common irrigation (100\% level). 
J.Soil Sci. and Agric. Eng., Mansoura Univ., Vol. 6(2), February , 2015

3-

221 
The data showed that as irrigation levels decreased, the reduction \% values of all the studied traits due to water stress were heightened. The highest reduction $\%$ values for all studied traits were accompanied with the lowest applied- $\mathrm{K}$ rate; $24 \mathrm{~kg} \mathrm{~K} \mathrm{~K}_{2} \mathrm{O}$ fed $^{-1}$ under $50 \%$ irrigation, nevertheless, progressive elevating in $\mathrm{K}$-applied rate could diminish such reduction $\%$. Under $75 \%$ and $50 \%$ irrigation level, the smallest reduction \% were accompanied with the highest $\mathrm{K}$ rate; $60 \mathrm{~kg} \mathrm{~K}_{2} \mathrm{O}$ fed ${ }^{-1}$. Whereas, under common irrigation $100 \%$, application of $60 \mathrm{~kg} \mathrm{~K}_{2} \mathrm{O}$ fed ${ }^{-1}$ positively enhanced all the studied traits compared to those recorded with $48 \mathrm{~kg} \mathrm{~K}_{2} \mathrm{O}$ fed

\section{Water use efficiency (WUE)}

Water use efficiency (WUE) values $\left(\mathrm{kg} \mathrm{m}^{3}\right)$ of green and dry forage yield and total three- cut yield are shown in Table (4).

Table (4): Water use efficiency of green and dry forage yield $\left(\mathrm{kg} \mathrm{m}^{-3}\right)$ of fodder cowpea as affected by irrigation water levels and application $\mathrm{K}$ rates (mean of two seasons).

\begin{tabular}{|c|c|c|c|c|c|c|c|c|c|}
\hline \multirow{2}{*}{$\begin{array}{l}\text { Treatment } \\
\text { Irrigation } \\
\text { levels(A) }\end{array}$} & \multirow{2}{*}{$\begin{array}{l}\text { Rates } \\
\text { of } \mathrm{K}_{2} \mathrm{O} \\
\text { (B) }\end{array}$} & \multicolumn{4}{|c|}{ WUE of green yield $\left(\mathrm{kg} \mathrm{m}^{-3}\right)$} & \multicolumn{4}{|c|}{ WUE of dry yield $\left(\mathrm{kg} \mathrm{m}^{-3}\right)$} \\
\hline & & Cut 1 & Cut 2 & ut 3 & $\begin{array}{l}\text { Total } \\
\text { yield }\end{array}$ & Cut 1 & Cut 2 & Cut 3 & $\begin{array}{l}\text { Total } \\
\text { yield }\end{array}$ \\
\hline \multirow{4}{*}{$100 \%$} & 2 & 97 & 563 & 32 & 997 & 288 & 233 & 208 & 72 \\
\hline & & & & & & & & & \\
\hline & $4 \varepsilon$ & 1.779 & 1.880 & 223 & 627 & 0.386 & 416 & 256 & 325 \\
\hline & 60 & 1.985 & 2.235 & 299 & & 0.368 & 79 & 284 & \\
\hline \multicolumn{2}{|c|}{$A_{1}$ Mean } & 1.765 & 1.855 & 1.162 & 592 & 0.323 & 363 & 245 & \\
\hline \multirow{4}{*}{$75 \%$} & 24 & 1.344 & 1.365 & 0.925 & 211 & 0.242 & 0.272 & 181 & 31 \\
\hline & & 91 & 1.472 & 0.953 & & 0.278 & 0.304 & 92 & \\
\hline & & 046 & 2.201 & 1.052 & & 0.343 & & 19 & \\
\hline & & 199 & 2.397 & 1.388 & & 0.389 & 89 & 83 & \\
\hline \multicolumn{2}{|c|}{$A_{2}$ Mean } & 1.795 & 1.859 & 1.080 & 1.578 & 0.313 & 0.380 & 0.219 & 0.304 \\
\hline \multirow{4}{*}{$0 \%$} & 24 & 1.624 & 1.051 & 0.816 & & 0.280 & 0.208 & 145 & \\
\hline & 36 & .736 & 1.267 & 0.915 & 1.303 & 0.288 & 0.268 & 0.160 & 32 \\
\hline & & & & 1.024 & & 0.320 & & & \\
\hline & 6 & 101 & 2.269 & 1.099 & 1.826 & 0.362 & 464 & .218 & .350 \\
\hline \multicolumn{2}{|c|}{$\mathrm{A}_{3}$ Mean } & 1.832 & 1.586 & 0.963 & 1.461 & 0.312 & 0.322 & 0.176 & 0.268 \\
\hline \multirow{4}{*}{$\begin{array}{l}\text { Means of K- } \\
\text { rates } \\
\text { (B) }\end{array}$} & 24 & 1.522 & 1.326 & 0.924 & 1.257 & 0.269 & 0.237 & 0.178 & \\
\hline & 36 & 1.677 & 1.493 & 0.987 & 1.389 & 0.290 & 0.308 & 0.195 & 0.262 \\
\hline & $4 \varepsilon$ & 1.897 & 1.946 & 1.100 & 1.648 & 0.332 & & 0.220 & \\
\hline & 60 & 2.095 & 2.300 & 1.262 & 1.880 & 0.373 & 0.477 & .261 & 74 \\
\hline \multicolumn{10}{|c|}{ L.S.D at $5 \%$} \\
\hline & & $\mathrm{ns}$ & 0.050 & 0.033 & & $\mathrm{~ns}$ & & 13 & 04 \\
\hline & 0.091 & 0.097 & 0.049 & 0.046 & 0.016 & 0.012 & 0.010 & 009 \\
\hline \multicolumn{2}{|l|}{$\mathrm{AxB}$} & 0.157 & 0.169 & 0.084 & 0.079 & 0.029 & 0.021 & 0.017 & 0.016 \\
\hline
\end{tabular}


The results elucidated that, irrespective of applied K-rate effect, the WUE of both green and dry yield of forage was slightly increased with decreasing the water levels, at the $1^{\text {st }}$ cut. But, at the $2^{\text {nd }}$ cut, the WUE of both yields; green and dry under $75 \%$ level was insignificantly higher than with $100 \%$ level and both of them was markedly increased than WUE with $50 \%$ level. As for the $3^{\text {rd }}$ cut and total yield, data showed that decreasing the irrigation water levels lowered the WUE of both yield.

With regard to, the applied K-rates effect, the results clarified that increasing the application rates of $\mathrm{K}$, under all water levels, substantially heightened the WUE of both green and dry yields, at all cuts, as well as the WUE of their total yields. It is of important to mention that the highest WUE values of fodder cowpea yields, for all yield parameters, were recorded with the treatment of $60 \mathrm{~kg} \mathrm{~K}_{2} \mathrm{O}$ fed ${ }^{-1}$ under $75 \%$ irrigation level. Whereas, the WUE values of all the obtained yields recorded with $60 \mathrm{~kg} \mathrm{~K}_{2} \mathrm{O}$ fed ${ }^{-1}$, under $100 \%$ and $50 \%$ irrigation levels came in the $2^{\text {nd }}$ and $3^{\text {rd }}$ orders, respectively. The results also, indicated that application of $48 \mathrm{~kg} \mathrm{~K}_{2} \mathrm{O}$ fed ${ }^{-1}$ under $75 \%$ irrigation level had markedly better effects on WUE of fresh and dry yield, at the $1^{\text {st }}$ and $2^{\text {nd }}$ cuts as well as total cut yield, than the same rate under $100 \%$ level, however, this was not true at the $3^{\text {rd }}$ cut. In this concern, Ghaznavi and Abdolshahi (2011) showed that application of $100 \mathrm{~kg} \mathrm{ha}^{-1}\left(41.7 \mathrm{~kg} \mathrm{fed}^{-1}\right)$ $\mathrm{K}_{2} \mathrm{SO}_{4}$ was much more beneficial in increasing yield of wheat under drought stress than under normal condition.

The beneficial effect of high $\mathrm{K}$ rate application on fodder cowpea yield under water stress could be attributed to improving water status of plants through reduction in transpiration rate and enhancement in the photosynthetic assimilation that might have contributed to better growth and productivity under this condition as reported by Umar (2006) and Hayatu and Mukhtar (2010)

\section{Carbohydrates \%, protein \%and ash contents}

Data shown in Table (4) indicated that total carbohydrates \%, crude proteins $\%$ and ash content ( $\mathrm{kg} \mathrm{fed}^{-1} \mathrm{DW}$ ) of fodder cowpea plants were negatively affected due to water deficit stress. The greater water deficit stress was the remarkable was the negative effect.

Lowering carbohydrates \% in cowpea plants could be explained as under limited water condition, especially under $50 \%$ irrigation, the plants reacted to water stress with rapid stomatal closure which limited $\mathrm{CO}_{2}$ influx into the leaf led to depression in photosynthesis that resulted in limited carbohydrate content as reported by Chaves (1991). Also, it could be as a result of decreased leaves number or area which reduced light interception area (Nam et al., 1998) that led to decline in carbon assimilation and its consequent low carbohydrate content.

Crude proteins content has a major role in increasing the quality of fodder crops. Reduced crude Proteins \% in cowpea under drought condition; 75 and $50 \%$ irrigation could be due to the effect of drought stress on nitrogen 
mobility, uptake or assimilation as $\mathrm{N}$ is a constituent of amino acids, proteins and nucleic acids (Marschner, 1995). The low soil water content may affect the mobility of nitrate ions which are transported from bulk soil to the roots through mass flow (Marschner, 1995), inhibit nitrogenase activity and $\mathrm{N}_{2-}$ fixation by cowpea plants (El Enany et al., 2013), reduce transport of $\mathrm{N}$ from root to shoot as a result of decreased transpiration rate (Tanguilig et al., 1987 ) or restrict the ability of plants to assimilate $\mathrm{N}$ by inhibiting the enzymes involving in $\mathrm{N}$ metabolism (Correia et al., 2005).

The significant declined in ash content (Table 5) in cowpea plants grown under water stress could generally due to the results of reduced soil nutrients availability and uptake with decreasing water soil content or as a consequence of limited energy source (carbohydrates) supplied by leaves being affected by drought. Our observations are in agreement with those of Zewdie et al., (2008).

Regarding the effect of different applied K-rates on Ash content of cowpea, the current results indicated that, under each level of irrigation, elevating the $\mathrm{K}$ application rate markedly enhanced ash content in cowpea plants, at the three cuts. The maximum ash content were found in cowpea plants received the highest $\mathrm{K}$ rate; $60 \mathrm{~kg} \mathrm{~K}_{2} \mathrm{O}$ fed ${ }^{-1}$ under $100 \%$ irrigation at the three cuts, however, the results revealed that the ash content of plants treated by $60 \mathrm{~kg} \mathrm{~K}_{2} \mathrm{O}$ fed ${ }^{-1}$ under $75 \%$ were higher than the value of ash content of plants treated by $24 \mathrm{~kg} \mathrm{~K}_{2} \mathrm{O}$ fed ${ }^{-1}$ under $100 \%$ in the $2^{\text {nd }}$ and $3^{\text {rd }}$ cuts. This may be ascribed as the higher applied rate of $\mathrm{K}, 60 \mathrm{~kg} \mathrm{~K}_{2} \mathrm{O}$ fed ${ }^{-1}$, could enhance the uptake of minerals under such water shortage condition.

Concerning the effect of K-rates on carbohydrates and protein \% of cowpea, the results showed that increasing $\mathrm{K}$-applied rates elevated the values of both concentrations, irrespective of irrigation levels. The highest $\mathrm{K}$ rate, $60 \mathrm{~kg} \mathrm{~K}_{2} \mathrm{O}$ fed $^{-1}$, by far accentuated both contents more than the other used $\mathrm{K}$ - rates did, under all levels of irrigation.

The eminent effect of applied high $\mathrm{K}$ rate on carbohydrates \%, proteins \% and ash content in cowpea plants could be ascribed to the role of $\mathrm{K}$ in enhancing plant tolerance to withstand drought stress through an increase in water-use efficiency, its function on stomatal regulation, osmoregulation or improved photosynthesis, protein synthesis and enhanced uptake of minerals by plants (Marschner, 1995 and Hu and Schmidhalter, 2005).

Statistical analysis revealed that there was a significant interaction effect between the irrigation levels and $\mathrm{K}$ applied rates on plant ash content at the three cuts as increasing water deficit stress lowered the ash content of cowpea and elevating $\mathrm{K}$ rates heightened it significantly, under all levels of irrigation. Nevertheless, this effect was mostly insignificant in the case of carbohydrates and proteins \%. 
Table (5): Effect of irrigation water levels and different application rates of $\mathbf{k}$ on carbohydrates (\%), protein (\%) and ash contents $(\mathbf{k g}$ fed $^{-1}$ DW) of fodder cowpea.

\begin{tabular}{|c|c|c|c|c|c|c|c|c|c|c|}
\hline \multirow{2}{*}{$\begin{array}{l}\text { Treatments } \\
\text { Water } \\
\text { levels } \\
\text { (A) } \\
\end{array}$} & \multirow{2}{*}{$\begin{array}{c}\text { Rates } \\
\text { of } \mathrm{K}_{2} \mathrm{O} \\
(\mathrm{B})\end{array}$} & \multicolumn{3}{|c|}{ Carbohydrates (\%) } & \multicolumn{3}{|c|}{ Protein (\%) } & \multicolumn{3}{|c|}{ Ash (kg fed ${ }^{-1}$ DW) } \\
\hline & & Cut 1 & Cut 2 & Cut 3 & ut 1 & Cut 2 & Cut 3 & Cut 1 & Cut 2 & Cut \\
\hline \multirow{4}{*}{$100 \%$} & 24 & 37.56 & .57 & 6.47 & 7.50 & 17.50 & 17.38 & 6.8 & 3.4 & 44.6 \\
\hline & 36 & 37.97 & 3.87 & 37.20 & 17.50 & 18.38 & 17.60 & 72.9 & 79.4 & 51.0 \\
\hline & 48 & 38.67 & 40.00 & 37.67 & 18.38 & 19.25 & 17.64 & 79.3 & 94.2 & 584 \\
\hline & 60 & & 41.30 & 8.13 & 9.16 & 19.50 & 19.25 & 5.5 & 7.6 & 9.9 \\
\hline \multicolumn{2}{|c|}{$A_{1}$ Mean } & 38.52 & 39.68 & 37.13 & 18.14 & 18.61 & 97 & 76.1 & 1.1 & 55.9 \\
\hline \multirow{4}{*}{$75 \%$} & 24 & 35.97 & 37.60 & 35.13 & 16.63 & 16.63 & 17.25 & 39.1 & 57.2 & 28.2 \\
\hline & 36 & 37.40 & 38.17 & 36.00 & 17.50 & 17.50 & 17.50 & 45.3 & 71.3 & 30.3 \\
\hline & 48 & 37.75 & 38.67 & 36.40 & 18.38 & 18.38 & 17.50 & 58.1 & 81.7 & 36.1 \\
\hline & 60 & 38.20 & 3 & 37.20 & 18.38 & 19.25 & 18.38 & 64.7 & 8.5 & 47.6 \\
\hline \multicolumn{2}{|c|}{$A_{2}$ Mean } & 37.33 & 38.60 & 36.35 & 17.72 & 17.94 & 17.66 & 51.8 & 74.7 & 35.5 \\
\hline \multirow{4}{*}{$50 \%$} & 24 & 33.77 & 34.73 & 31.87 & 15.75 & 16.66 & 16.63 & 27.7 & 20.4 & 13.3 \\
\hline & 36 & 34.50 & 36.07 & 33.17 & 16.63 & 16.63 & 17.25 & 31.1 & 25.7 & 16.3 \\
\hline & 48 & 35.00 & 37.00 & 34.80 & 17.50 & 17.50 & 17.25 & 34.8 & 38.0 & 19.4 \\
\hline & 60 & 36.20 & 37.57 & 35.97 & 18.38 & 18.38 & 18.40 & 39.7 & 1.0 & 23.8 \\
\hline \multicolumn{2}{|c|}{$A_{3}$ Mean } & 34.89 & 36.34 & 33.75 & 17.07 & 17.29 & 17.38 & 33.3 & 33.8 & 18.2 \\
\hline \multirow{4}{*}{$\begin{array}{l}\text { Means of K- } \\
\text { rates } \\
\text { (B) }\end{array}$} & 24 & 35.56 & 36.67 & 34.71 & 16.63 & 16.93 & 17.09 & 44.5 & 50.3 & 28.7 \\
\hline & 36 & 36.62 & 37.70 & 35.46 & 17.21 & 17.51 & 17.45 & 49.7 & 58.7 & 32.5 \\
\hline & 48 & 37.14 & 38.56 & 36.29 & 18.09 & 18.38 & 17.46 & 57.4 & \begin{tabular}{|l|}
71.3 \\
\end{tabular} & 37.9 \\
\hline & 60 & 38.12 & 39.61 & 37.10 & 18.67 & 18.96 & 18.68 & 63.3 & 85.7 & 47.1 \\
\hline \multicolumn{11}{|c|}{ L.S.D at $5 \%$} \\
\hline \multicolumn{2}{|l|}{$\frac{\mathrm{A}}{\mathrm{B}}$} & 0.58 & \begin{tabular}{|l|l|}
0.81 \\
\end{tabular} & 0.51 & 0.73 & 0.36 & 0.24 & 1.7 & 9.2 & 2.0 \\
\hline$B$ & & 0.59 & 0.56 & 0.44 & 0.39 & 0.36 & 0.24 & 2.8 & 3.9 & 1.4 \\
\hline \multicolumn{2}{|l|}{$A \times B$} & ns & ns & 0.77 & ns & ns & ns & 4.8 & 6.8 & 2.5 \\
\hline
\end{tabular}

$\mathrm{K}$ concentration in Leaf

Testing concentration of $\mathrm{K} \%$ (Table 6) showed that leaf- $\mathrm{K}$ concentration declined as water deficit stress was aggravated, in the $1^{\text {st }}$ and $2^{\text {nd }}$ cuts. This may be due to the effect of low soil moisture content which induces poor diffusion of $\mathrm{K}$ ions into plant roots and consequently lowering $\mathrm{K}$ content in the plants. In this regard, Hu and Schmidhalter (2005) reported similar observations,

Statistical analysis showed insignificant differences, in terms of $\mathrm{K} \%$, among the three water levels in the $3^{\text {rd }}$ cut. The highest concentrations of $\mathrm{K}$ were detected in the plant leaf treated by $60 \mathrm{~kg} \mathrm{~K}_{2} \mathrm{O}$ fed ${ }^{-1}$ then $48 \mathrm{~kg} \mathrm{~K}_{2} \mathrm{O}$ fed 1 , grown under $75 \%$ and $50 \%$ irrigation levels, respectively. This might be a kind of adaptation to cope with drought stress due to the important role of $\mathrm{K}$ in alleviating the adverse effect of water stress. 
Table (6): Potassium concentration (\%) in leaves and micronutrient contents of shoot ( $\mathrm{g} \mathrm{fed}^{-1} \mathrm{DW}$ ) of fodder cowpea as affected by water irrigation levels and application rates of $\mathrm{K}$ (mean of two seasons).

\begin{tabular}{|c|c|c|c|c|c|c|c|c|c|c|c|c|c|}
\hline \multirow{2}{*}{$\begin{array}{l}\text { Treatments } \\
\text { Water } \\
\text { levels (A) }\end{array}$} & \multirow{2}{*}{$\begin{array}{c}\text { Rates } \\
\text { of } \mathrm{K}_{2} \mathrm{C} \\
\text { (B) }\end{array}$} & \multicolumn{3}{|c|}{$\mathrm{K}(\%)$} & \multicolumn{3}{|c|}{$\mathrm{Fe}\left(\mathrm{g} \mathrm{fed}^{-1}\right)$} & \multicolumn{3}{|c|}{$\mathrm{Zn}\left(\mathrm{g} \mathrm{fed}^{-1}\right)$} & \multicolumn{3}{|c|}{$\operatorname{Mn}\left(\mathrm{g} \mathrm{fed}^{-1}\right)$} \\
\hline & & c & c & Cut 3 & Cut 1 & $\mathrm{Cu}$ & 2. Cut & $\mathrm{Cu}$ & $\mathrm{Cu}$ & $2 \mathrm{Cu}$ & Cut 1 & 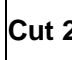 & Cut 3 \\
\hline \multirow{4}{*}{$100 \%$} & 24 & 1.75 & 1.65 & 1.77 & 107.3 & 97.0 & 8.1 & 25.8 & 26.3 & 13.5 & 14.5 & 19.1 & 0.0 \\
\hline & 36 & 1.76 & 1.71 & 1.87 & 118.4 & 114.6 & \begin{tabular}{l|l}
668.8 \\
\end{tabular} & 33.9 & 35.9 & 18.5 & 18.2 & 23.2 & 2.1 \\
\hline & 48 & 1.93 & 1.70 & 1.93 & 2 & 135.4 & \begin{tabular}{|l|l|}
4 & 82.1
\end{tabular} & 8.9 & 9.7 & 21.8 & 9.0 & 0.0 & r \\
\hline & 60 & 35 & 1.77 & 1.93 & 4 & & 91.4 & .4 & 5 & 26.9 & 2.3 & .6 & 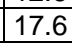 \\
\hline \multicolumn{2}{|l|}{$\mathrm{A}_{1}$ Mean } & 1.82 & 1.71 & \begin{tabular}{|l|}
1.87 \\
\end{tabular} & 124.1 & 130.2 & 75.1 & 4.1 & 3 & 20.2 & 18.5 & .0 & 3.1 \\
\hline \multirow{4}{*}{$75 \%$} & 24 & 1.62 & 1.60 & 1.65 & 48.3 & \begin{tabular}{|l|}
76.7 \\
\end{tabular} & 36.3 & 15.2 & 7 & 10.3 & 6.2 & 3 & 4 \\
\hline & $3 t$ & 1.62 & 1.65 & 1.85 & 56.6 & 98.5 & 39.0 & 19.6 & 24.6 & 10.8 & 9.3 & 5.2 & 5.1 \\
\hline & 48 & 1.69 & 1.75 & 2.20 & 83.2 & 124.9 & 45.2 & 28.0 & 30.7 & 14.0 & 13.0 & 21.6 & 9.1 \\
\hline & 60 & 1.77 & 1.85 & 2.12 & 93.2 & 140.5 & 62.8 & 34.4 & 38.1 & 18.5 & 15.6 & 26.1 & 12.9 \\
\hline \multicolumn{2}{|l|}{$\mathrm{A}_{2}$ Mean } & 1.68 & 1.71 & 1.96 & 70.3 & 10.1 & 45.8 & 24.3 & 28.0 & 13.4 & 11.0 & 19.0 & 7.9 \\
\hline \multirow{4}{*}{$50 \%$} & 6 & 1.65 & 1.50 & 1.57 & & & 6 & .3 & & 3.6 & 3.4 & 4 & 34 \\
\hline & 3 & 1.65 & 1.55 & 1.88 & 35 & 35.7 & 18.2 & 11.5 & & 4.4 & 4.0 & 6.1 & 4.3 \\
\hline & 48 & 1.66 & 1.62 & 2.15 & 47.9 & 55.0 & 22.8 & 15.6 & 13.0 & 6.7 & 6.4 & 8.7 & 5.6 \\
\hline & 60 & 1.70 & 1.70 & 2.11 & 57.1 & 75.5 & 30.5 & 18.7 & 20.3 & 8.7 & 8.0 & 13.4 & 7.1 \\
\hline \multicolumn{2}{|l|}{$\mathrm{A}_{3}$ Mean } & 1.67 & 1.59 & 1.93 & 42.6 & \begin{tabular}{|l|}
47.3 \\
\end{tabular} & 22.1 & 14.0 & 12.0 & 5.0 & 5.4 & 8.2 & 5.1 \\
\hline \multirow{4}{*}{$\begin{array}{l}\text { Means of K- } \\
\text { rates } \\
\text { (B) }\end{array}$} & 24 & 1.67 & 1.58 & 1.66 & 62.0 & 65.6 & 37.0 & 17.1 & 17.2 & 9.1 & 8.1 & 12.3 & 6.0 \\
\hline & 3 & \begin{tabular}{|l|}
1.67 \\
\end{tabular} & 1.64 & 1.87 & 70 & \begin{tabular}{|l|}
82.9 \\
\end{tabular} & 42.0 & 21.5 & 22.9 & 11.2 & 10.5 & 14.9 & 7.2 \\
\hline & 4 & 1.76 & 1.69 & 2.09 & 86 & 105.1 & 50.0 & 27.5 & 27.8 & 14.2 & \begin{tabular}{|l}
12.8 \\
\end{tabular} & 20.1 & 9.1 \\
\hline & 60 & 1.77 & 1.77 & 2.05 & 97.2 & 129.9 & 61.6 & 31.8 & 35.3 & 18.0 & 15.3 & 23.7 & 12.6 \\
\hline \multicolumn{14}{|c|}{ L.S.D at $5 \%$} \\
\hline \multirow{2}{*}{\multicolumn{2}{|c|}{ A }} & 0.05 & 0.03 & ns & 2.2 & 10.6 & 1.8 & 1.3 & 3.5 & 0.5 & 1.2 & 1.1 & 0.3 \\
\hline & & 0.05 & 0.01 & 0.07 & 4.2 & 6.1 & 1.3 & 1.3 & 2.1 & 0.9 & 0.8 & 0.9 & 0.7 \\
\hline \multicolumn{2}{|l|}{$A \times B$} & 0.09 & 0.04 & 0.12 & 7.2 & 10.6 & 2.3 & 2.3 & ns & 1.6 & 1.3 & 1.6 & 1.3 \\
\hline
\end{tabular}

\section{Micronutrient contents in cowpea plants}

Content of some key micronutrients by fodder cowpea plants (Table, 6) were studied namely, Fe, $\mathrm{Zn}$ and $\mathrm{Mn}$ content $\left(\mathrm{g} \mathrm{fed}^{-1}\right)$. The contents of these nutrients were notably reduced in plants as the irrigation levels decreased at the three cuts. Nevertheless, progressive elevating of $\mathrm{K}$ rates considerably heightened these contents in plants; under each irrigation levels. But, the adverse effect of water stress appeared more sever on such contents with the lowest irrigation levels; $50 \%$, as the recovery seemed better with $75 \%$ level than $50 \%$. In this regard, $\mathrm{Hu}$ and Schmidhalter (2005) stated that because the transport of micronutrients to the plant roots occurs via diffusion, low soil content will reduce micronutrient uptake.

The higher contents of the studied micronutrients were obtained under the normal irrigation level; $100 \%$ especially with the highest K-rate; 60 $\mathrm{kg} \mathrm{K}_{2} \mathrm{O}$ fed $^{-1}$. This could presumably be due to the increased absorption of these nutrients by plants and the increased biomass of cowpea plants accompanied this treatment. On the other hand, the lower contents were present in plants received $24 \mathrm{~kg} \mathrm{~K}_{2} \mathrm{O}$ fed ${ }^{-1}$, under $50 \%$ irrigation level. In this concern, Havlin et al., (1999) reported that low soil moisture induces deficiencies in $\mathrm{Mn}, \mathrm{Mo}, \mathrm{Fe}$, and $\mathrm{Zn}$, and under moist condition, $\mathrm{Mn}$ and $\mathrm{Fe}$ become increasingly available because of its conversion to reduced and 
more soluble form. Also, Hsiao (1973) mentioned that drought may affect the nutritional status in plants at the level of nutrient uptake and long distance transport in xylem and phloem.

In the current study, under each level of irrigation, the highest $\mathrm{Fe}, \mathrm{Zn}$ and $\mathrm{Mn}$ uptake by cowpea plants were accompanied with $60 \mathrm{~kg} \mathrm{~K}_{2} \mathrm{O}$ fed treatment, at all cuts. The improvement of micronutrient contents of fodder cowpea plants by high $\mathrm{K}$ rates application could be one of the mechanisms that enhanced the tolerance of cowpea under stress water conditions. In this concern, Marschner (1995) indicated that micronutrients improve nutritive status of plants and protect them against adverse effect of environmental conditions.

\section{CONCLUSION}

Increasing water deficit stress notably affected the physiological processes and some nutrients uptake by fodder cowpea plants. As a consequence their growth and development were severely affected reflecting on the productivity and quality of its forage yield. It reduced both green and dry yield and decreased the forage nutrient contents; carbohydrates, proteins and minerals contents. Application of potassium, especially, at higher rate; 60 $\mathrm{kg} \mathrm{K}_{2} \mathrm{O} \mathrm{fed}^{-1}$, could appreciably improve the water status and physiological performance of fodder cowpea plants under $75 \%$ level of irrigation that enabled them to produce forage yield close to obtained by $36 \mathrm{~kg} \mathrm{~K}_{2} \mathrm{O}$ fed ${ }^{-1}$, under normal conditions.

\section{REFERENCES}

Aboelill, A.A.; H.M. Mehanna; O.M. Kassab and E.F. Abdallah (2012). The response of peanut crop to foliar spraying with potassium under water stress condition. Australian J. Basic Applied Sci., 6(8):626-634.

Allen, R.G.; L.S. Pereeira; D. Raes and M. Smith (1998). Crop Evapotraspiration. Guideline for computing crop water requirements. Irrig. And Drain. Paper, No. 56, FAO, Rome, Italy.

Anderson, M.N.; C.R. Jensen and R. Losch (1992). The interaction effect of potassium and drought in field-grown barely. 1-Yield, water-use efficiency and growth. Soil Plant Sci., 42: 34-44.

AOAC (1990). Official Methods of Analysis. $15^{\text {th }}$ ed., Association of Official Analytical Chemists, Washington.

Bajji, M.; J.M. Kinet and S. Lutts (2002). The use of the electrolyte leakage method for assessing cell membrane stability as a water stress tolerance test in durum wheat. Plant Growth Regulation. 36: 61-70.

Baker, F.W.G. (1989). Drought Resistance in Cereals. CAB International, Wallingford, UK.

Benlloch-Gonzalez, M.; J. Romera; S. Cristescu; F. Harren; J.M. Fournier and M. Benlloch (2012). $\mathrm{K}^{+}$starvation inhibits water-stress-induced stomatal closure via ethylene synthesis in sunflower plants. J. Exp. Bot., 61(4):1139-1145. 
Black, C.A.; D.D. Evans; L.E. Ensminger; G.L. White and F.E. Clark (1982). Methods of Soil Analysis. Am, Soc. Agron. Inc., Pub. Madison, Wisconsin, USA.

Cakmak, I. (2005). The role of potassium in alleviating detrimental effects of abiotic stresses in plants. J. Plant Nutr. Soil Sci., 168: 521- 530.

Chapman, H.D. and P.F. Pratt (1982). Method of Plant Analysis. I. Method of Analysis for Soil, Plant and Water. Chapman Pub., Riverside, California, USA.

Chaves, M.M. (1991). Effect of water deficits on carbon assimilation. J. Exp. Bot., 42:1-16.

Correia, M.J.; F. Fonesca; J. Azedo; C. Dias et al., (2005). Effect of water deficit on the activity of nitrate reductase and content of sugars, nitrate and free amino acids in the leaves and roots of sunflower and white lupin plants grown under two regimes of nutrient supply. Physiological Plantarum, 124: 61-70.

Creamer, N.G. and K.R. Baldwin (1999). Summer cover crops. North Carolina State University, North Carolina Cooperative Extension Service, Horticulture Information Leaflets. No. 37.

Dakkak, A. (2013). Egypt 's Water Crisis- Recipe for Disaster. http|lwww.info@ecomena.org.

Dubois, M.; A. Gilles; J.K. Hamelton; P.A. Robers and P.A. Smith (1956). A colorimetric method for determination of sugar and related substances. Annals Chem., 28: 2-350-356.

El-Enany, A.E.; A.D. Al-Anazi; N. Dief; W.A. Al-Taisan (2013). Role of antioxidant enzymes in amelioration of water deficit and waterlogging stresses on Vigna sinensis plants. J. Biol. and Earth Sci., 3(1): B144B153.

El-Sarag Eman, I. (2013). Cowpea-sorghum mixtures as affected by water stress levels and forage mixing ratio in semi-arid regions. World $\mathrm{J}$. Agric. Sci., 9(4): 325-334.

FAO (2013). Grassland Index. A Searchable catalogue of grass and forage legumes. FAO, Rome, Italy.

Fatthallah, M.A. and Gawish Ragaa, A. (1997). Effect of Taro intercropping with some vegetable crops on growth, yield and productivity in relation to several soil- moisture regimes. Minufiya J. Agric. Res., 22(60): 1647-1675.

Fischer, R.A. and T.C. Hsiao (1968). Stomatal opening in isolated epidermal strips of Vicia faba. II. Response to $\mathrm{KCl}$ concentrations and the role of potassium absorption. Plant Physiol., 43: 1953-1958.

Ghaznavi, A.F. and R. Abdolshahi (2011). Study on effect of potassium sulphate on drought tolerance of bread wheat (Triticum aestivum L.). Ecophysiology, 3:87-93.

Havlin, J.L.; J.D. Beaton; S.L. Tisdale and W.L. Nelson (1999). Soil Fertility and Fertilizers: An Introduction to Nutrient Management. PrenticeHall, Inc., London, p. 406-425. 
Hayatu, M. and F.B. Mukhtar (2010). Physiological responses of drought resistant cowpea genotypes (Vigna unguiculata (L.) Walp) to water stress. Bayero j. Pure and Applied Sci., 3(2): 69-75.

Heuzé V.; G. Tran; D. Bastianelli; F. Lebas and P. Nozière (2013). Cowpea (Vigna unguiculata) forage. http://www.feedipedia.org/node/23September 2013, 20 - 42.

Hsiao, T.C. (1973). Plant response to water stress. Ann. Rev. Plant physiol., 24:517-570.

$\mathrm{Hu}, \mathrm{Y}$. and U. Schmidhalter (2005). Drought and salinity: A comparison of their effect on mineral nutrition of plants. J. Plant Nutr. Soil Sci., 168:541-549.

IITA (1989). Cowpea Research at International Institute for Tropical Agriculture (IITA) GLIP Research Monograph, No. (1) Ibadan, Nigeria.

Jensen, M. E. (1983). Design and operation of farm irrigation systems. Amer. Soc. Agric. Eng., Michigan,USA.

Karamanos, A.S. (1980). Water stress and leaf growth of field bean (Vicia faba) in the field: leaf number and total area. Annals Bot., 42:13931402.

Karigoudar, A.S. and S.S. Angadi (2005). Influence of seed rate, row spacing and fertility levels on yield and quality of field bean for forage production. Karnataka J. Agric. Sci., 18(2):489-491.

Kassab, O.M.; S.A. Orabi and A.A. AboEllil (2012). Physiological response to potassium application in fodder beet plant grown under water stress. Austral. J. basic and Appl. Sci., 6(13): 566-574.

Ledbetter, K. (2005). Cowpea could add sustainability to cropping system. Texas A\&M AgriLife Today.

Madamba, R.; G.J.H. Grubben; I.K. Asante and R. Akromah (2006). Vigna unguiculata (L.) Walp. Brink, M. and Belay, G. (Eds.), PROTA (Plant Resources of Tropical Africa), Wageningen, Netherlands.

Marschner, H. (1995). Mineral Nutrition of Higher Plants. $2^{\text {rd }}$ ed., Academic Press, London, U K.

Mullen, C. (1999). Summer legume forage crops: cowpeas, lablab, soybeans. NSW Department of Primary Industries. Broad acre crops. Agfact P4.2.16.

Nam, N.H.; G.U. Subbarno; Y.S. Chauhan and C. Johabsen (1998). Importance of canopy attributes in determining dry matter accumulation of pigeon pea under contrasting moisture regimes. Crop Sci., 38: 955-961.

Okon, J.E. (2013). Effect of water stress on some growth aspects of two varieties of cowpea, Vigna unguiculata (L.) Walp Fabaceae. Bull. Environ. Pharmacol. Life Sci., 2(5): 69-74.

Page, A.L.; R.H. Miller and D.R. Keeney (1982). Methods of Soil Analysis. Part 2. $2^{\text {nd }}$ editions Am, Soc. Agron. Inc., Pub. Madison, Wisconsin, USA. 
Piper, C.S. (1950). Soil and Plant Analysis. Inter. Sci. Pub. Inc., New York, p.368.

Samar Raza, M.A.; M. Farrukh Saleem; G. Mustafa Shah; M. Jamil and I. Haider Khan (2013). Potassium applied under drought improves physiological and nutrient uptake performances of wheat (Triticum aestivum L.). J. soil Sci. and Plant Nutr., 13(1): 175-185.

Sambo, B.E.; E.C. Odion; L. Aliyu and D.A. Labe (2013). Cowpea (Vigna unguiculata (L.) Walp) clipping management technology. 1: A potential for fodder production, sustained growth and food security in the Savannah regions of Nigeria. J. Agricultural and Crop Research 1(3): $36-45$.

Sánchez, F.J.; E.F de Andree.; J.L. Tenorio and L. Ayerbe (2004). Growth of epicotyls, turgor maintenance and osmotic adjustment in pea plants (Pisum sativum L.) subjected to water stress. Field Crops Research, 86(1):91-90.

Sangakkara, U.R.; M. Frehner and J. Nosberger (2000). Effect of soil moisture and potassium fertilizer on shoot water potential, photosynthesis and partitioning of carbon in mungbean and cowpea. J. Agron. Crop Sci., 185: 73-81.

Singh, B.B; H.A Ajeigbe; S.A Tarawali; S. Fernandez-Rivera; M. Abubakar (2003). Improving the production and utilization of cowpea as food and fodder. Field Crops Research, 84:169-177.

Soleimanzadeh, H.; D. Habibi; M.R. Ardakam; F. Paknejad and F. Rejali (2010). Response of sunflower (Helianthus annuus L.) to droght stress under different potassium levels. World Appl. Sci. J., 8(4): 443448.

Steel, R.G.D. and J.H. Torrie (1984). Principles and Procedures of Statistics: A biometric approach, $2^{\text {nd }}$ eds., McGraw Hill Book co., New York, USA.

Tanguilig, V.C.; E.B. Yambao; J.C. O Toole and S.K. Dedatta (1987). Waterstress effect on leaf elongation, leaf water potential, transpiration and nutrient-uptake of rice, maize and soybean. Plant Physiol. 93:471-478.

Umar, S. (2006). Alleviating adverse effects of water stress on yield of sorghum, mustard and groundnut by potassium application. Pak. J. Bot., 38(5): 1373-1380.

Umar, S. and L. Moinuddin (2002). Genotypic differences in yield and quality of ground nut as affected by potassium nutrition under rainfull condition. J. Plant Nutr., 25: 1549-1562.

Wang, W.; B. Vinocur and A. Altman (2003). Plant response to drought, salinity and extreme temperature: towards genetic engineering for stress tolerance. Planta. 218:1-14.

Wang, M.; Q. Zheng; Q. Shen and Sh.Guo (2013). The critical role of potassium in plant stress response. Int. J. Mol. Sci., 14: 7370-7390.

Zareian, A.; H.H. Abad; A. Hamidi; G.N. Mohammadi; and S.A. Tabatabaei (2013). Effect of drought stress and potassium foliar application on some physiological indices of three wheat (Triticum aestivum L.) cultivars. Annals Biol. Res., 4(5): 71-74. www.scholarsresearchlibrary.co 
Zewdie, S.; M. Olsson and M. Fetene (2008). Effect of drought/irrigation on proximate composition and carbohydrate content of two enset (Ensete ventricosum (Welw) Cheesman) clones. Ethiop. J. Sci., 31(2):91-88.

Zlatev, Z. and F.C. Lidon (2012). An overview on drought induced change in plant growth, water relations and photosynthesis. J Food Agric. 24(1): 57-72.

مقاومة الإجهاد المسائي لنبات لوبيا العلف تحت تأثير المستويات المختلفة المضـافة

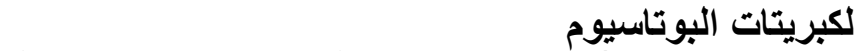

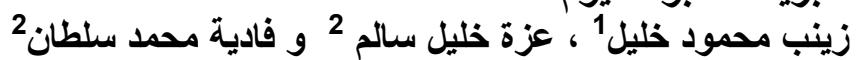

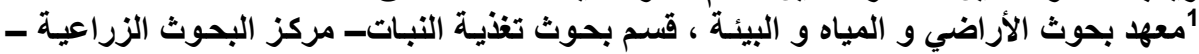

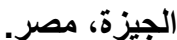
2معهز المحاصيل الحقلية، قسم بحوث العلف- مركز البحوث الزراعية ــ الجيزة، مصر.

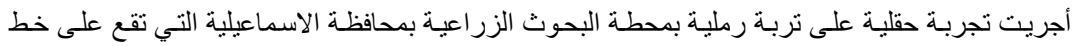

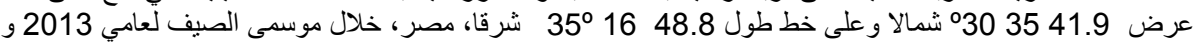

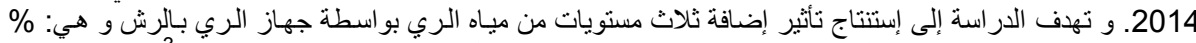

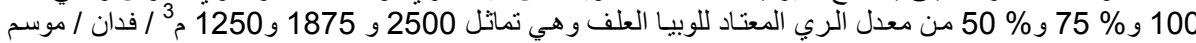

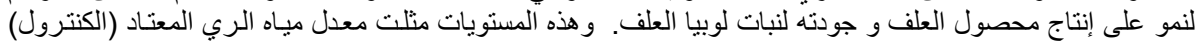

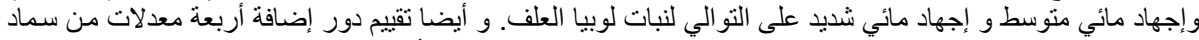

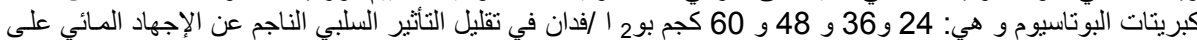

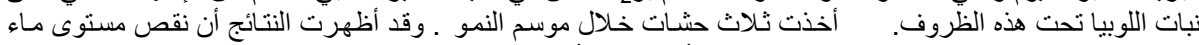

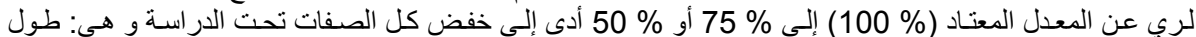

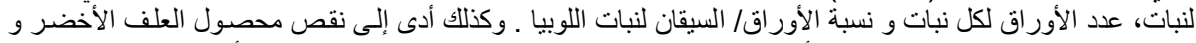

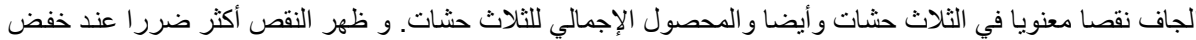

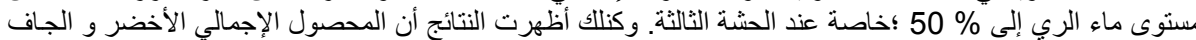

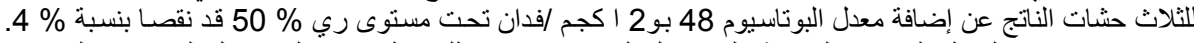

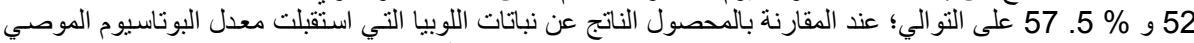

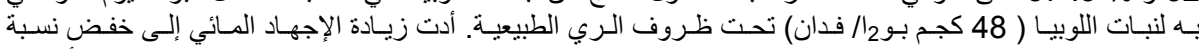

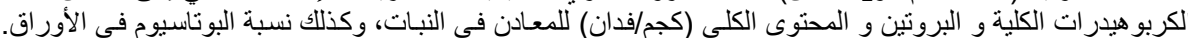

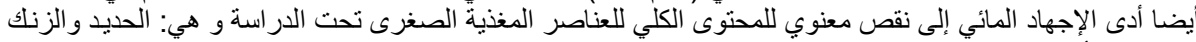

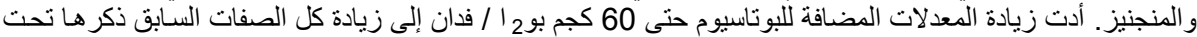

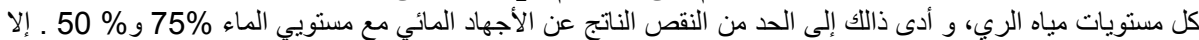

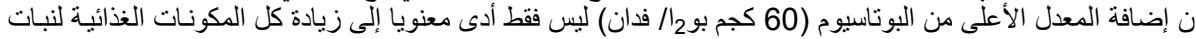

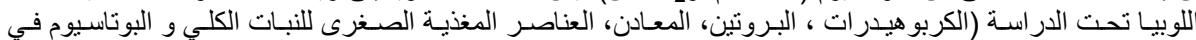

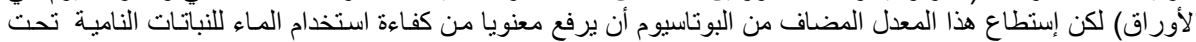

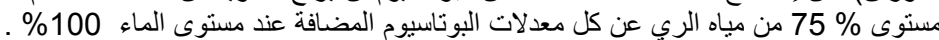

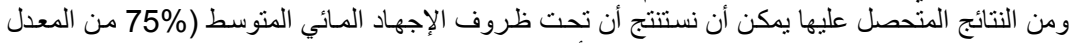

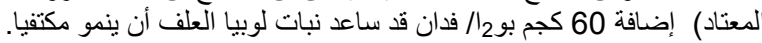


Table (3): Relative change (\%) of the studied traits as affected by irrigation water levels and rates of $\mathrm{K}$ compared with those at $48 \mathrm{~kg} \mathrm{~K}_{2} \mathrm{O}$ fed $^{-1}$, under $100 \%$ irrigation level.

\begin{tabular}{|c|c|c|c|c|c|c|c|c|c|c|c|c|c|c|c|}
\hline \multirow{2}{*}{\multicolumn{2}{|c|}{$\begin{array}{l}\text { character } \\
\text { Treatment }\end{array}$}} & \multicolumn{3}{|c|}{ Plant height } & \multicolumn{3}{|c|}{ Leaves Number } & \multicolumn{4}{|c|}{ Green forage yield } & \multicolumn{4}{|c|}{ Dry forage yield } \\
\hline & & $\begin{array}{c}\text { Cut } \\
1\end{array}$ & $\begin{array}{c}\text { Cut } \\
2\end{array}$ & $\begin{array}{c}\text { Cut } \\
3\end{array}$ & $\begin{array}{c}\text { Cut } \\
1\end{array}$ & $\begin{array}{c}\text { Cut } \\
2\end{array}$ & $\begin{array}{c}\text { Cut } \\
3\end{array}$ & $\begin{array}{c}\text { Cut } \\
1\end{array}$ & $\begin{array}{c}\text { Cut } \\
2\end{array}$ & $\begin{array}{c}\text { Cut } \\
3\end{array}$ & $\begin{array}{l}\text { Total } \\
\text { yield }\end{array}$ & $\begin{array}{c}\text { Cut } \\
1\end{array}$ & $\begin{array}{c}\text { Cut } \\
2\end{array}$ & $\begin{array}{c}\text { Cut } \\
3\end{array}$ & $\begin{array}{l}\text { Total } \\
\text { yield }\end{array}$ \\
\hline \multirow{4}{*}{$100 \%$} & 24 & 9.6 & 10.4 & 16.1 & 28.6 & 30.0 & 21.1 & 10.3 & 16.8 & 15.7 & 14.2 & 13.3 & 17.5 & 18.8 & 16.4 \\
\hline & 36 & 6.4 & 6.3 & 8.2 & 10.7 & 6.7 & 15.8 & 4.5 & 7.4 & 10.5 & 6.3 & 8.4 & 9.3 & 9.4 & 9.0 \\
\hline & 48 & 0 & 0 & 0 & 0 & 0 & 0 & 0 & 0 & 0 & 0 & 0 & 0 & 0 & 0 \\
\hline & 60 & +9.3 & +2.8 & +6.0 & +14.3 & $\begin{array}{r}+10.0 \\
\end{array}$ & +15.8 & +11.5 & +15.3 & +6.2 & +11.6 & +10.8 & +23.7 & +10.9 & +16.0 \\
\hline \multirow{4}{*}{$75 \%$} & 24 & 36.2 & 7.6 & 12.1 & 50.0 & 56.7 & 36.8 & 43.4 & 45.5 & 43.5 & 44.2 & 45.8 & 47.4 & 46.9 & 46.7 \\
\hline & 36 & 26.6 & 14.6 & 23.5 & 35.7 & 43.3 & 31.6 & 33.0 & 41.3 & 41.5 & 38.3 & 37.3 & 41.2 & 43.8 & 40.6 \\
\hline & 48 & 14.9 & 26.0 & 36.5 & 32.1 & 33.3 & 21.1 & 13.7 & 12.1 & 35.6 & 18.6 & 22.9 & 12.4 & 35.9 & 22.1 \\
\hline & 60 & 8.5 & 34.4 & 45.6 & 25.0 & 20.0 & 5.3 & 7.2 & 5.2 & 14.4 & 11.9 & 12.0 & 5.2 & 17.2 & 10.7 \\
\hline \multirow{4}{*}{$50 \%$} & 24 & 52.1 & 55.2 & 68.2 & 64.3 & 63.3 & 57.9 & 54.4 & 72.1 & 66.7 & 64.3 & 57.8 & 74.2 & 71.9 & 68.0 \\
\hline & 36 & 40.4 & 47.9 & 62.4 & 60.7 & 60.0 & 52.6 & 51.2 & 65.7 & 62.7 & 60.0 & 56.6 & 67.0 & 68.8 & 63.9 \\
\hline & 48 & 35.4 & 39.6 & 52.8 & 53.6 & 56.7 & 42.1 & 47.6 & 53.2 & 58.2 & 52.4 & 51.8 & 55.7 & 65.6 & 57.0 \\
\hline & 60 & 30.9 & 28.1 & 47.1 & 46.4 & 47.7 & 31.6 & 40.9 & 39.6 & 55.2 & 43.9 & 45.8 & 40.2 & 57.8 & 46.7 \\
\hline
\end{tabular}

The values given with $60 \mathrm{~kg} \mathrm{~K}_{2} \mathrm{O}$ fed $^{-1}$, under $100 \%$, are positive change \%, while the others exhibit negative change \%; compared with $48 \mathrm{~kg} \mathrm{~K}_{2} \mathrm{O}$ fed $^{-1}$, under $100 \%$. 